\section{ANTIPAIN, A NEW PROTEASE INHIBITOR ISOLATED FROM ACTINOMYGETES}

\section{Sir :}

Specific enzyme inhibitors of microbial origin have been studied in the authors' laboratory and as reported in previous papers, leupeptins ${ }^{1 \sim 5)}$ inhibiting plasmin, trypsin, kallikrein and papain, pepstatin ${ }^{6 \sim 9)}$ inhibiting acid proteases, and chymostatin ${ }^{16)}$ inhibiting chy motrypsins have been isolated. These inhibitors were found in culture filtrates of various species of actinomycetes. In this paper, the isolation and properties of antipain are reported.

Antipain was found in culture filtrates of various species of actinomycetes and two strains were studied in detail: strain $\mathrm{MB}$ 561-C 2 which resembles Streptomyces michigaensis $^{12 \sim 13)}$; strain MC 829-ASI which resembles Streptomyces yokosukanensis ${ }^{14 \sim 15)}$. The same compound was also found by $S$. UMEZAWA et al. ${ }^{11}$ in their study of SAKAGUCHI-positive products in a culture filtrate of strain KC84-AG13 which is closely related to Actinomyces violascens ${ }^{16)}$ and Streptomyces mauvecolor ${ }^{17)}$ and the structure was determined.

Activity of antipain was measured by the following method: one $\mathrm{ml}$ of $2.0 \%$ casein solution, $0.5 \mathrm{ml}$ of borate buffer $(\mathrm{pH} 7.4)$ and $0.3 \mathrm{ml}$ of the same buffer with or without a test material were mixed and incubated for 3 minutes; then, $0.2 \mathrm{ml}$ of a solution of papain $(500 \mu \mathrm{g} / \mathrm{ml}$, dissolved in the same buffer) was added. After the reaction mixture was incubated for $30 \mathrm{mi}$ nutes at $37^{\circ} \mathrm{C}, 2.0 \mathrm{ml}$ of $1.7 \mathrm{M}$ perchloric acid was added and the extinction of the supernatant separated from the precipitate was read at $280 \mathrm{~m} \mu$; the percent inhibition was calculated by the formula $\frac{a-b}{a} \times 100$, wherein $a$ is the absorbance of the reaction mixture without antipain, and $b$ is the absorbance of the reaction mixture with antipain. Addition of $0.32 \mu \mathrm{g}$ of antipain to the reaction mixture (that is $0.16 \mu \mathrm{g} / \mathrm{ml}$ ) produced $50 \%$ inhibition.
In a medium containing $2.0 \%$ glucose, $1.0 \% \mathrm{~N}-\mathrm{Z}$ amine, $0.2 \%$ yeast extract, $0.3 \%$ $\mathrm{NaCl}, 0.1 \% \quad \mathrm{MgSO}_{4} \cdot 7 \mathrm{H}_{2} \mathrm{O}, 0.1 \% \mathrm{~K}_{2} \mathrm{HPO}_{4}$, $0.0007 \% \quad \mathrm{CuSO}_{4} \cdot 5 \mathrm{H}_{2} \mathrm{O}, 0.0001 \% \quad \mathrm{FeSO}_{4} \cdot 7$ $\mathrm{H}_{2} \mathrm{O}, \quad 0.0008 \% \mathrm{MnCl}_{2} \cdot 4 \mathrm{H}_{2} \mathrm{O}, 0.0002 \% \mathrm{Zn}-$ $\mathrm{SO}_{4} \cdot 7 \mathrm{H}_{2} \mathrm{O}$, production of antipain reached a maximum after $2 \sim 3$ days in shake culture or $22 \sim 28$ hours in tank fermentation. The $\mathrm{pH}$ of the broth and the percent inhibition of papain by $0.005 \mathrm{ml}$ of the broth in an example were as follows: on 1 st day, $\mathrm{pH}$ $7.7,52 \%$ inhibition; on 2 nd day, $\mathrm{pH} 6.5$, $87 \%$; on $3 \mathrm{rd}$ day, pH $6.5,87 \%$, on 4 th day, $\mathrm{pH} 8.3,53 \%$, on 5 th day, $\mathrm{pH} 8.6$, $12 \%$; on 6 th day, $\mathrm{pH} 8.5,5 \%$; on 8 th day, $\mathrm{pH} 8.8,0 \%$.

When 6 liters of 72-hour cultured broth were inoculated in 300 liters of the medium described above in a 500-liter fermentor, after 25 hours at $28^{\circ} \mathrm{C}$ under aeration and stirring, the $\mathrm{pH}$ was 7.4 and $0.037 \mathrm{ml}$ of a 10 times diluted culture filtrate produced $50 \%$ inhibition. The filtrate was adjusted to $\mathrm{pH} 4.9$ with $6 \mathrm{~N} \mathrm{HCl}$ and passed through a column (48 liters, $20 \mathrm{~cm}$ in diameter) of Amberlite IRC -50 ( $\mathrm{H}^{+}-$form). After the column was washed with 150 liters of distilled water, antipain was eluted with 200 liters of $0.5 \mathrm{~N} \mathrm{HCl}-80 \% \mathrm{MeOH}$. The active eluate (150 liters) was neutralized and concentrated and dried in vacuo. The dried active material was dissolved in 20 liters of methanol and the filtrate was concentrated in vacuo and lyophylized. The crude powder $(30 \mathrm{~g})$ thus obtained was dissolved in $300 \mathrm{ml}$ of distilled water, and after adjusting to $\mathrm{pH} 7.0$ this solution was subjected to the carbon column chromatography (1.2 liter), using $0.025 \mathrm{~N} \mathrm{HCl}$ $80 \% \mathrm{MeOH}$. The active fraction was

Fig. 1. Chromatography on CM-Sephadex C-25.
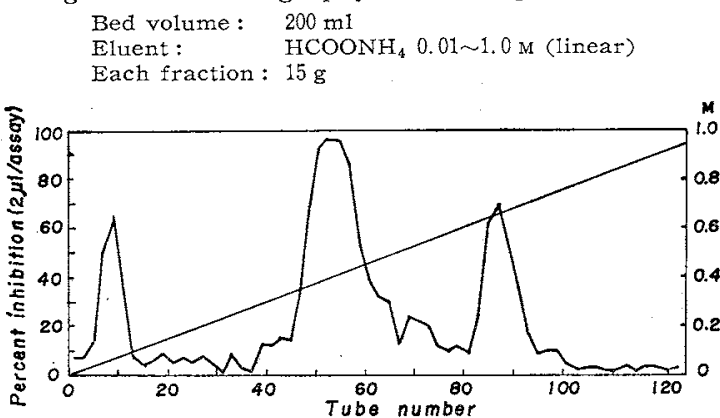
neutralized with Amberlite IR-45 $\left(\mathrm{OH}^{-}-\right.$ form) and evaporated in vacuo, yielding $5.0 \mathrm{~g}$ of a pale yellow powder. Addition of $7.5 \mu \mathrm{g}$ of this powder to the reaction mixture produced $50 \%$ inhibition of papain $\left(\mathrm{ID}_{50}=7.5 \mu \mathrm{g}\right)$. The powder was further purified by CM-Sephadex C-25 column chromatography with a gradient of ammonium formate from $0.01 \mathrm{M}$ to $1.0 \mathrm{M}$. Antipain appeared in the fraction obtained using $0.4 \mathrm{M}$ ammonium formate concentration. Antipain in the eluate was adsorbed by carbon, and eluted with $0.05 \mathrm{~N}$ $\mathrm{HCl}-80 \%$ methanol. Evaporation of the eluate yielded antipain dihydrochloride.

Anal.: C 46.60, H 7.43, N 19.40, O 15.05, Cl 9.80 .
Fig. 2. Ultraviolet absorption spectrum of antipain (1.16 $\mathrm{mg} / \mathrm{ml}$ in water).

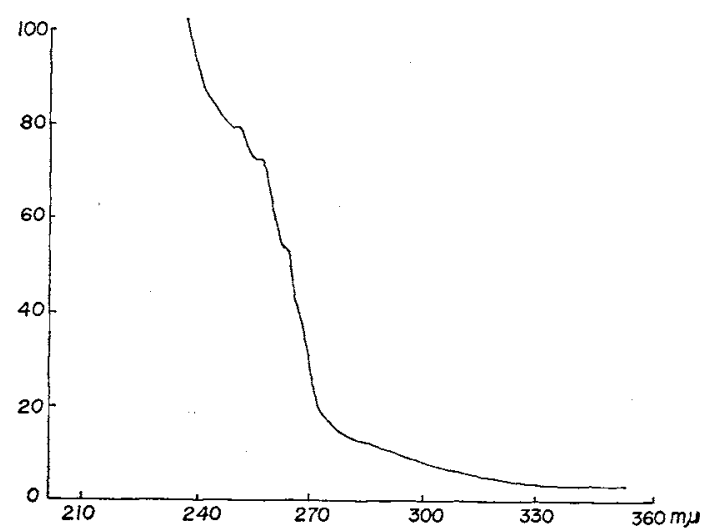

Table 1. Effect of leupeptin, pepstatin, chymostatin and antipain against various proteases

\begin{tabular}{|c|c|c|c|c|c|}
\hline \multirow{2}{*}{ Enzymes } & \multirow{2}{*}{ Substrates } & \multicolumn{4}{|c|}{$\mathrm{ID}_{50} \quad(\mu \mathrm{g} / \mathrm{ml})$} \\
\hline & & Leupeptin & Pepstatin & Chymostatin & Antipain \\
\hline Thrombokinase & $\overline{\text { Plasma }}$ & $\overline{15}$ & $>250$ & $>250$ & 20 \\
\hline Thrombin & $\mathrm{TAME}^{1)}$ & 10,000 & $>250$ & $>250$ & $>250$ \\
\hline Plasmin & Fibrinogen & 8 & $>250$ & $>250$ & 93 \\
\hline Trypsin & Casein & 2 & $>250$ & $>250$ & 0.26 \\
\hline Papain & Casein & 0.5 & $>250$ & 7.5 & 0.16 \\
\hline Kallikrein & $\mathrm{BAEE}^{2)}$ & 75 & $>250$ & $>250$ & $>250$ \\
\hline$\alpha$-Chymotrypsin & Casein & $>500$ & $>250$ & 0.15 & $>250$ \\
\hline $\begin{array}{l}\beta, \gamma \text { and } \delta \text {-Chymo- } \\
\text { trypsin }\end{array}$ & Casein & $>500$ & $>250$ & 0.15 & $>250$ \\
\hline Pepsin & $\begin{array}{l}\text { Casein } \\
\text { Hemoglobin }\end{array}$ & $\begin{array}{l}>500 \\
>500\end{array}$ & $\begin{array}{l}0.01 \\
0.0031\end{array}$ & $\begin{array}{l}>250 \\
>250\end{array}$ & $\begin{array}{l}>250 \\
>250\end{array}$ \\
\hline Proctase A & Casein & $>250$ & $>250$ & $>250$ & $>250$ \\
\hline Proctase B & Casein & $>250$ & 0.0072 & 26.5 & 190 \\
\hline Cathepsin A & Cb-Glut-Tyr $\left.{ }^{3}\right)$ & 1,680 & $>125$ & 62.5 & \\
\hline Cathepsin B & $\mathrm{BAA}^{4)}$ & 0.44 & $>125$ & 2.6 & \\
\hline Cathepsin D & Hemoglobin & 109 & 0.011 & 49.0 & \\
\hline
\end{tabular}

Fig. 3. Infrared absorption spectrum of antipain hydrochloride $(\mathrm{KBr})$.

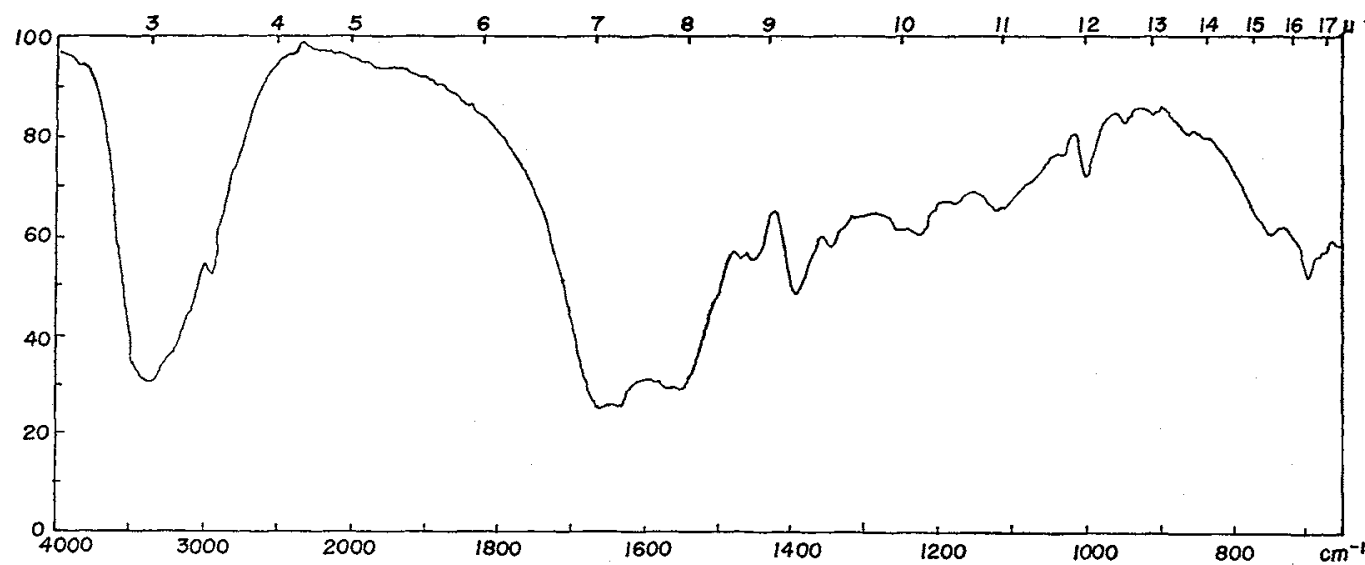


Properties of antipain dihydrochloride are as follows: m. p. $170 \sim 177^{\circ} \mathrm{C} ;[\alpha]_{\mathrm{D}}^{20}-10^{\circ}$ (c 1, $\left.\mathrm{H}_{2} \mathrm{O}\right)$; maxima at $247 \mathrm{~m} \mu\left(\mathrm{E}_{1 \mathrm{~cm}}^{1 \%} 7.09\right)$, $252 \mathrm{~m} \mu \quad\left(\mathrm{E}_{1 \mathrm{~cm}}^{1 \%} 6.83\right), 257 \mathrm{~m} \mu \quad\left(\mathrm{E}_{\mathrm{icm}}^{1 \%} 6.29\right)$, $263 \mathrm{~m} \mu\left(\mathrm{E}_{1 \mathrm{~cm}}^{1 \%} 4.64\right), 267 \mathrm{~m} \mu\left(\mathrm{E}_{1 \mathrm{~cm}}^{1 \%} 3.48\right)$ in $\mathrm{H}_{2} \mathrm{O}$ (Fig. 2). The IR spectrum is shown in Fig. 3. It is soluble in water, methanol and dimethylsulfoxide, less soluble in ethanol, propanol and butanol, insoluble in benzene, hexane, petroleum ether, ethyl ether and chloroform. It gives positive RrDon-Smith, permanganate, Sakaguchi, and negative ninhydrin reactions. It gives the following Rf values in thin-layer chromatography: 0.4 by $n$-butanol-butyl acetateacetic acid-water $(4: 2: 1: 1)$ on silica-gel G, 0.55 by $n$-butanol-ethanol-water ( 4 : $1: 2$ ) on cellulose (Avicel) and $\operatorname{Rf} 0.36$ by $n$-butanol - ethanol - $17 \%$ aqueous ammonia $(3: 1: 2)$ on cellulose. It moves to the cathode in formic acid-acetic acid-water $(25: 75: 900)$ under $3500 \mathrm{~V}$ electrophoresis for 15 minutes with an $\mathrm{Rm}$ value of 0.9 taking L-alanine as 1.0 .

The activities of antipain inhibiting various proteases were examined using methods described in previous papers ${ }^{2,8}$ and the results are shown in Table 1 together with the activities of leupeptin, chymostatin and pepstatin. In the structure reported by S. UMEZAWA et al. in another paper ${ }^{11}$, an argininal moiety which has been found in leupeptin is also present in antipain. Comparing with leupeptin, antipain is more specific to papain and trypsin. Activity of antipain in inhibiting fibrinogenolysis by plasmin is much weaker than that of leupeptin. Antipain at $100 \mu \mathrm{g} / \mathrm{ml}$ showed no antibacterial and no antifungal activity. The intraperitoneal injection of $1.0 \mathrm{~g} / \mathrm{kg}$ and the intravenous injection of $125 \mathrm{mg} / \mathrm{kg}$ to mice caused no death and the intravenous injection of $250 \mathrm{mg} / \mathrm{kg}$ caused death of all mice.

The effect of antipain on carrageenin edema was determined using the method described by WINTER et al. ${ }^{18)}$ Intraperitoneal injection of $50 \mathrm{mg} / \mathrm{kg}$ of antipain caused $40 \%$ inhibition. Antipain, which inhibits thrombokinase, inhibits blood coagulation. This effect was studied in comparison with leupeptin and heparin. It showed a similar strength of inhibition as leupeptin and the type of inhibition is the same as leupeptin and different from heparin.

Isolation of leupeptin and antipain indicates that actinomycetes produce various types of protease inhibitors containing arginial.

Hiroyuki Suda
Takani Aoyagi
Masa Hamada
Tomo Takeuchi
Hamao Umezawa

Institute of Microbial Chemistry, Shinagawa-ku, Tokyo, Japan

(Received February 9, 1972)

\section{References}

1) Aoyagi, T.; T. Takeuchi, M. Matsuzaki, K. Kawamura, S. Kondo, M. Hamada, K. MAEDA \& H. UmEZaWA: Leupeptins, new protease inhibitors from actinomycetes. J. Antibiotics $22: 283 \sim 286,1969$

2) Aoyagi, T.; S. Mryata, M. Nanbo, F. Kojima, M. Matsuzairi, M. Ishizuka, T. Takeuchi, \& H. UMEZAWA : Biological activities of leupeptins. J. Antibiotics $22: 558 \sim 568,1969$

3) Kondo, S.; K. Kawamura, J. Iwanaga, M. Hamada, T. Aoyagi, K. Maeda, T. Takeuchi \& H. UMEZAWA : Isolation and characterization of leupeptins produced by actinomycetes. Chem. Pharm. Bull. $17: 1896 \sim 1901$, 1969

4) Kawamura, K.; S. Kondo, K. Maeda \& H. UMEZAWA: Structures and synthesis of leupeptins Pr-LL and Ac-LL. Chem. Pharm. Bull. $17:$ 1902 1909, 1969

5) Maeda, K.; K. Kawamura, S. Kondo, T. Aoyagi, T. Takeuchi \& H. Umezawa: The structure and activity of leupeptins and related analogs. J. Antibiotics $24: 402 \sim$ 404, 1971

6) Umezawa, H.; T. Aoyagi, H. Morishima, M. Matsuzaki, M. Hamada \& T. Takeuchi: Pepstatin, a new pepsin inhibitor produced by actinomycetes. J. Antibiotics $23: 259 \sim$ 262, 1970

7) Morishima, H.; T. Takita, T. Aoyagi, T. TAKeucrir \& H. UmezaWa: The structure of pepstatin. J. Antibiotics $23: 263 \sim 265$, 1970

8) Aoyagi, T.; S. Kunimoto, H. Morismima, T. TAKEUCHI \& H. UMEZAWA: Effect of pepstatin on acid proteases. J. Antibiotics 24 : $687 \sim 694,1971$ 
9) Kunimoto, S.; T. Aoyagi, H. Morishima, T. TAKEUCHI \& H. UMEZAWA: Inhibitory mechanism of pepstatin to pepsin. J. Antibiotics $25: 235 \sim 239,1972$

10) Umezawa, H.; T. Aoyagi, H. Morishima, S. Kunmoto, M. Matsuzaki, M. Hamada \& T. TAkeuchi : Chymostatin, a new chymotrypsin inhibitor produced by actinomycetes. J. Antibiotics $23: 425 \sim 427,1970$

11) Umezawa, S.; K. Tatsuta, K. Fujimoto, T. Tsuchiya, H. Umezawa \& H. Naganawa : Structure of antipain, a new SakaguchIpositive product of Streptomyces. J. Antibiotics 25: $\sim, 1972$

12) Shirling, E. B. \& D. Gottureb : Cooperative description of type cultures of Streptomyces. II. Species descriptions from first study. Internat. J. System. Bacteriol. 18: 146, 1968

13) Corbaz, R.; L. Etrimiser, W. KellerSchierlein \& H. Zähner: Zur Systematik der Actinomyceten. Archiv f. Mikrobiol. $26: 205 \sim 206,1957$

14) Shirling, E. B. \& D. Gotthieb : Cooperative description of type cultures of Streptomyces. IV. Species descriptions from the second, third and fourth studies. Internat. J. System. Bacteriol, $19: 502 \sim 504,1969$

15) Nakamura, G.: Studies on antibiotic actinomycetes. III. On Stereptomyces producing 9- $\beta$-D-ribofuranosylpurine. J. Antibiotics $14: 94 \sim 97,1961$

16) Shirling, E. B. \& D. Gottlieb : Cooperative description of type cultures of Streptomyces. III. Additional species descriptions from first and second studies. Internat. J. System. Bacteriol. $18: 380 \sim 382,1968$

17) Murase, M.; T. Hikiri, K. Nitta, Y. Okam, T. TAkeuchi \& H. Umezawa: Peptimycin, a product of Streptomyces exhibiting apparent inhibition against EHRLICH carcinoma. J. Antibiotics 14: 113 118, 1961

18) Winter, C. A.; E. A. Risley \& G. W. Nuss : Carrageenin-induced edema in hind paw of the rat as an assay for antiinflammatory drugs. Proc. Soc. Expt1. Biol. \& Med. 111: $544 \sim 547,1962$ 